\title{
A study on China's Agricultural Products Exports to Kazakhstan Based on CMS Model
}

\author{
Huiqing Sun ${ }^{1, *}$, Qingrou Zhong ${ }^{2, *}$ \\ ${ }^{1}$ Xinhua College of Sun Yat-sen University, School Economics \&Trade, Guangzhou, China \\ ${ }^{2}$ Harbin University of Science and Technology, School Economics \&Management, Harbin, China
}

\begin{abstract}
This article applies the modified CMS model and selects the data about exports of China's agricultural products to Kazakhstan from 1998 to 2019 according to SITC (Rev.3) so as to make an empirical analysis of the factors influencing the growth of China's agricultural products exports to Kazakhstan based on both the overall and classification perspectives. The results show that the structural change effects promoted the growth of China's agricultural products exports to Kazakhstan before the "Belt and Road" initiative was proposed, followed by the inhibiting effect. The competitiveness effect is inhibitory, and then it is promoting. The interaction effects before and after the "Belt and Road" initiative was proposed are both inhibitory.
\end{abstract}

\section{Introduction}

In the first half of 2020, the COVID-19 spread around the world, leading to poor transportation, the delay of trade fair, and temporary restrictions on exports in some major grain exporting countries, which has had a major impact on world agricultural trade. In the post-epidemic era, the "Belt and Road" initiative would make an important contribution to global economic recovery. The "Belt and Road" initiative, proposed in 2013, is of great significance to the promotion of China's new round of opening up and the common development of countries along the routes. Kazakhstan is located at the junction of the Eurasian continent and is an important transportation hub connecting China and Europe, so it's role in the "Belt and Road" strategy cannot be ignored. Since establishing diplomatic relations, China and Kazakhstan have maintained rapid economic and trade development. At present, the process of agricultural trade liberalization between China and Kazakhstan is accelerating and the scale of China's agricultural exports to Kazakhstan is expanding.

\section{Literature}

The current research about agricultural products exports from China to Kazakhstan focus on two aspects: one is to analyze the comparative advantages, complementarity and potential of China's agricultural products export to Kazakhstan by using trade indexes (Liu Xiaobo \& Chen Tong (2009); Zhang Xiaoqian \& Gong Xinshu (2014); Han Jingjing \& Wei Feng (2017)). Second, model analysis. Among them, Cheng Yunjie \& Sun Zhiming (2020) used ternary marginal decomposition framework; Meng Xinyue (2014) used gravity model; Hu Ying (2009) and Gong Xinshu, Zhang et al. (2014) analyzed the growth factors of China's export of agricultural products to Kazakhstan by using the CMS model of the data according to HS96. Above all, the current research for China's agricultural products export to kazakhstan is relatively rich, but in view of "Belt And Road" is less, so this article applies the CMS model which used by $\mathrm{Lu}$ yanping \& Xiao haifeng (2019), and selects the agricultural products export data from 1998 to 2019 on the standard of SITC (rev.3), combined with the "Belt And Road" initiative, and analyze the influence factors of China's agricultural products export to kazakhstan from both a whole and classification (category 0 which the largest part of agricultural products export) perspective.

\section{The status of China agricultural products' export to Kazakhstan}

\subsection{The scale of agricultural products' export has been expanding from China to Kazakhstan}

As shown in Table1, China's agricultural exports to Kazakhstan increased by 272 million US dollars from 1998 to 2019. In 2019, the proportion of China's agricultural exports to Kazakhstan in Kazakhstan's total agricultural products' imports increased by $2.6 \%$ compared with 1998. Affected by the Asian financial crisis, China's export volume of agricultural products to Kazakhstan in 2001 decreased by 7 million US dollars compared with 1998. From 2002 to 2008, China's export volume of agricultural products to Kazakhstan increased by 95 million US dollars, which was a significant increase compared with the period of 1998 to 2001 . In 
2009, China's agricultural exports to Kazakhstan increased by 3 million US dollars compared with 2008 . In 2013, Kazakhstan joined the "Belt and Road" initiative as the first country. The trade of agricultural products between the two countries developed further from 2014 to 2019. In 2019, the export volume of agricultural products from China to Kazakhstan reached 296 million US dollars, and the export volume continued to expand and showed a fluctuating upward trend.

Table 1. The total value of agricultural products' export From China to Kazakhstan.

\begin{tabular}{|c|c|c|}
\hline Year & $\begin{array}{c}\text { Total value } \\
\text { (100 million } \\
\text { USD) }\end{array}$ & $\begin{array}{c}\text { The Proportion on total } \\
\text { imports of agricultural } \\
\text { products from the world } \\
\text { (\%) }\end{array}$ \\
\hline 1998 & 0.24 & 4.81 \\
\hline 1999 & 0.11 & 2.87 \\
\hline 2000 & 0.13 & 32.07 \\
\hline 2001 & 0.17 & 2.87 \\
\hline 2002 & 0.29 & 5.05 \\
\hline 2003 & 0.35 & 4.65 \\
\hline 2004 & 0.30 & 3.00 \\
\hline 2005 & 0.54 & 3.81 \\
\hline 2006 & 0.54 & 2.93 \\
\hline 2007 & 0.85 & 3.38 \\
\hline 2008 & 1.24 & 3.90 \\
\hline 2009 & 1.27 & 4.89 \\
\hline 2010 & 1.39 & 5.72 \\
\hline 2011 & 1.76 & 4.19 \\
\hline 2012 & 1.94 & 4.36 \\
\hline 2013 & 2.36 & 4.94 \\
\hline 2014 & 2.38 & 5.35 \\
\hline 2015 & 2.39 & 6.87 \\
\hline 2016 & 2.19 & 7.04 \\
\hline 2017 & 3.15 & 8.84 \\
\hline 2018 & 3.11 & 8.28 \\
\hline 2019 & 2.96 & 7.40 \\
\hline
\end{tabular}

\subsection{The structure of agricultural products' exports is unbalanced}

According to SITC Rev.3, this paper divides agricultural products into four categories: Category 0, Category 1, Category 2 (excluding Chapter 27 and 28), and Category 4.

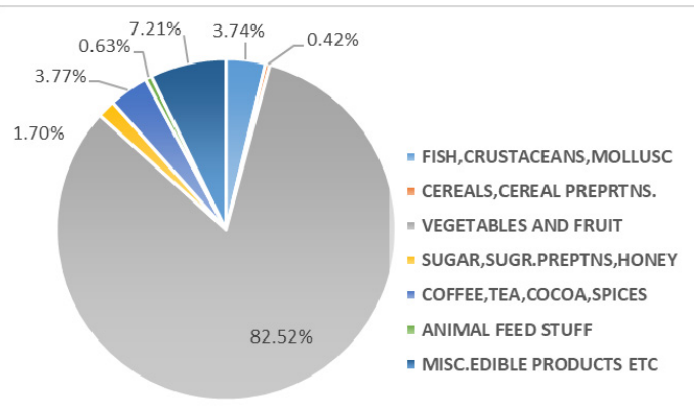

Fig. 1. The proportion of different types of agricultural products' exports of category 0 from China to Kazakhstan
As shown in Table2, from 1998 to 2019, China's export of agricultural products to Kazakhstan has mainly concentrated in Category 0, accounting for more than 95\% except 2000 and 2001, and the export volume has been increasing year by year. The share of category 1,2 and 4 is very small. The main export of category 0 is vegetables and fruits, which reached 236 million US dollars in 2019, accounting for $82.52 \%$ of the total amount of category 0 , as shown in Figure 1. It can be seen that China's comparative advantage is vegetable and fruit. The export volume of the four types of agricultural products is in the trend of rising volatility. In the future, the agricultural trade between China and Kazakhstan has great potential for development, but at the same time, the export structure of agricultural products is unbalanced.

Table 2. The Value and proportion of different categories of agricultural products exported by China to Kazakhstan

Uint: dollars; \%

\begin{tabular}{|c|c|c|c|c|}
\hline \multirow{2}{*}{ Year } & \multicolumn{2}{|c|}{ Category 0} & \multicolumn{2}{|c|}{ Category 1} \\
\hline & Value & proportion & Value & proportion \\
\hline 1998 & 22953094 & 97.30 & 533009 & 2.26 \\
\hline 1999 & 11179159 & 97.40 & 264164 & 2.30 \\
\hline 2000 & 11525379 & 85.43 & 1841955 & 13.65 \\
\hline 2001 & 14580834 & 88.08 & 1541808 & 9.31 \\
\hline 2002 & 28329899 & 96.75 & 194907 & 0.67 \\
\hline 2003 & 33883809 & 97.34 & 510668 & 1.47 \\
\hline 2004 & 29498391 & 97.87 & 319302 & 1.06 \\
\hline 2005 & 52114048 & 96.82 & 310012 & 0.58 \\
\hline 2006 & 51541573 & 95.23 & 736521 & 1.36 \\
\hline 2007 & 81020767 & 95.11 & 1907219 & 2.24 \\
\hline 2008 & 120751322 & 97.68 & 662750 & 0.54 \\
\hline 2009 & 123683624 & 97.27 & 54180 & 0.04 \\
\hline 2010 & 132308897 & 95.21 & 109746 & 0.08 \\
\hline 2011 & 168544299 & 95.97 & 320383 & 0.18 \\
\hline 2012 & 188867109 & 97.44 & 173691 & 0.09 \\
\hline 2013 & 229906818 & 97.53 & 206342 & 0.09 \\
\hline 2014 & 228947595 & 96.25 & 2021078 & 0.85 \\
\hline 2015 & 230296132 & 96.26 & 709233 & 0.30 \\
\hline 2016 & 208557928 & 95.36 & 7020548 & 3.21 \\
\hline 2017 & 308768363 & 97.87 & 3307415 & 1.05 \\
\hline 2018 & 299759606 & 96.41 & 6353607 & 2.04 \\
\hline 2019 & 286199748 & 96.81 & 6434816 & 2.18 \\
\hline \multirow{2}{*}{ Year } & \multicolumn{2}{|c|}{ Category 2} & \multicolumn{2}{|c|}{ Category 4} \\
\hline & Value & proportion & Value & proportion \\
\hline 1998 & 102687 & 0.44 & 1944 & 0.01 \\
\hline 1999 & 33854 & 0.29 & 0 & 0 \\
\hline 2000 & 122926 & 0.91 & 0 & 0 \\
\hline 2001 & 430597 & 2.60 & 0 & 0 \\
\hline 2002 & 383855 & 1.31 & 373835 & 1.28 \\
\hline 2003 & 384569 & 1.10 & 30000 & 0.09 \\
\hline 2004 & 320516 & 1.06 & 2370 & 0.01 \\
\hline 2005 & 719586 & 1.34 & 684220 & 1.27 \\
\hline 2006 & 1466739 & 2.71 & 379786 & 0.70 \\
\hline 2007 & 1488486 & 1.75 & 772958 & 0.91 \\
\hline 2008 & 1868028 & 1.51 & 337508 & 0.27 \\
\hline 2009 & 3325877 & 2.62 & 95510 & 0.08 \\
\hline 2010 & 6444156 & 4.64 & 99397 & 0.07 \\
\hline 2011 & 6597579 & 3.76 & 165524 & 0.09 \\
\hline 2012 & 4739184 & 2.45 & 43414 & 0.02 \\
\hline 2013 & 5244591 & 2.22 & 368155 & 0.16 \\
\hline 2014 & 6657286 & 2.80 & 245978 & 0.10 \\
\hline 2015 & 7975823 & 3.33 & 251061 & 0.10 \\
\hline 2016 & 2979732 & 1.36 & 136534 & 0.06 \\
\hline 2017 & 3277061 & 1.04 & 145644 & 0.05 \\
\hline 2018 & 4653209 & 1.50 & 151088 & 0.05 \\
\hline 2019 & 2901152 & 0.98 & 108412 & 0.04 \\
\hline
\end{tabular}




\section{Empirical analysis}

\subsection{Data selection}

According to the trend of China's agricultural exports to Kazakhstan and taking into account the Asian financial crisis, China's accession to the WTO, the world financial crisis in 2008 and the "Belt and Road" initiative, these have a significant impact on Sino-Kazakh agricultural trade. This article selected the data from 1998 to 2019 to construct a CMS model, and then divided into four stages: the first stage is 1998-2001; the second stage is 2002-2008; the third stage is 2009-2013; the fourth stage is $2014-2019$.

\subsection{Model Construction}

CMS model was proposed by Tyszynski in 1951. At present, this model is mainly applied to study the influencing factors of export fluctuations and international competitiveness. Drawing on the model construction of Lu Yanping \& Xiao Haifeng (2019), this paper draws the modified single market CMS model to analyze the influencing factors of China's agricultural products' exports to Kazakhstan. This model mainly decomposes two levels:

The first level of decomposition:

$$
\Delta \mathrm{q}=\sum_{i} S_{i}^{0} \Delta Q i+\sum_{i} Q_{\mathrm{i}}^{0} \Delta S_{i}+\sum_{i} \Delta S_{i} \Delta Q_{\mathrm{i}}
$$

The second level of decomposition:

$$
\begin{array}{r}
\Delta \mathrm{q}=S^{0} \Delta Q+\left(\sum_{i} S_{i}^{0} \Delta Q i-S^{0} \Delta Q\right)+\Delta S Q^{0}+\left(\sum_{i} Q_{\mathrm{i}}^{0} \Delta S_{i}-\Delta S Q^{0}\right) \\
+\left(\frac{Q^{1}}{Q^{0}}-1\right) \sum_{\mathrm{i}} \Delta S_{\mathrm{i}} Q_{i}^{0}+\left[\sum_{i} \Delta S_{i} \Delta Q_{\mathrm{i}}-\left(\frac{Q^{1}}{Q^{0}}-1\right) \sum_{\mathrm{i}} \Delta S_{i} \Delta Q_{\mathrm{i}}^{0}\right]
\end{array}
$$

$\Delta \mathrm{q}$ represents the changes of agricultural products' exports from China to Kazakhstan. $\sum_{i} S_{i}^{0} \Delta Q_{i}$ represents the structural change effect which can be decomposed into world growth effect $\left(S^{0} \Delta Q\right)$ and commodity effect ( $\left.\sum_{i} S_{i}^{0} \Delta Q i-S^{0} \Delta Q\right)$. $\sum_{i} Q_{i}^{0} \Delta S_{i}$ presents the competitiveness effects which can be decomposed into comprehensive competitiveness effects $\left(\Delta S Q^{0}\right)$ and commodity competitiveness effects ( $\left.\sum_{i} Q_{\mathrm{i}}^{0} \Delta S_{i}-\Delta S Q^{0} \quad\right)$; $\sum_{i} \Delta S_{i} \Delta Q_{\mathrm{i}}$ presents the interaction effect which can be decomposed into Pure second-order effect $\left(\left(\frac{Q^{1}}{Q^{0}}-1\right) \sum_{\mathrm{i}} \Delta S_{\mathrm{i}} Q_{i}^{0}\right)$ and dynamic second-order effect $\left(\sum_{i} \Delta S_{i} \Delta Q_{\mathrm{i}}-\left(\frac{Q^{1}}{Q^{0}}-1\right) \sum_{\mathrm{i}} \Delta S_{i} \Delta Q_{\mathrm{i}}^{0}\right)$.

\subsection{Statistical Analysis}

\subsubsection{Results analysis on overall view}

(1) Structural change effect promotes the China's agricultural exports to Kazakhstan before the "Belt and Road" initiative was proposed, but creates inhibition after the proposition of "Belt and Road".
As shown in Table 3, the main factor that promotes the growth of China's agricultural exports to Kazakhstan is the structural change effect. The structural change effects of 2002-2008 and 2009-2013 were 145.8\% and $111.47 \%$ respectively, indicating that before the "Belt and Road" initiative was proposed, the adjustment of Kazakhstan's agricultural products import structure and the expansion of import scale promoted China's agricultural products' export to Kazakhstan.

The second level decomposition of the CMS model shows that the world growth effect and commodity effect are consistent with the direction of the structure effect, and the growth effect is the more significant factor affecting the growth of China's agricultural exports to Kazakhstan. Among them, the contribution rate of growth effect from 2002 to 2008 reached $139 \%$, indicating that China's entry into the WTO and the establishment of SCO promoted the expansion of the scale of agricultural products import in the market of Kazakhstan. From 2009 to 2013, the contribution of growth effect on China's agricultural exports to Kazakhstan reached 106 million US dollars, and the contribution rate was $97.86 \%$. Compared with the growth effect, the contribution rate of commodity effect is small. The commodity effect only accounts for $6.80 \%$ from 2002 to 2008 and $13.61 \%$ from 2009 to 2013, indicating that whether China's agricultural products exports are concentrated on the agricultural products with faster import growth in Kazakhstan has little influence on the agricultural products exports from China to Kazakhstan.

After the "Belt and Road" Initiative was put forward, the structural effect, growth effect and commodity effect all turned from positive to negative, inhibiting the growth of China's agricultural exports to Kazakhstan. From 2014 to 2019, the contribution rates of structural effect and growth effect were $-50.62 \%$ and $-42.27 \%$, respectively.

(2) Competitiveness effect has a restraining effect before the "Belt and Road" initiative was proposed, but a promoting effect after it is put forward.

As shown in Table3, competitiveness effect has become the main factor on promoting agricultural products exports from China to Kazakhstan after "Belt and Road" initiative put forward, the comprehensive competitiveness effect is the main influencing factors. The comprehensive competitiveness effect and the commodity competitiveness effect have opposite effects on the growth of China's agricultural exports to Kazakhstan before and after the "Belt and Road" initiative was put forward.

The competitiveness effect gradually increases during the period of 1998-2019. From 1998 to 2001, the competitiveness effect was $-138.58 \%$, which reduced China's export to Kazakhstan by USD 9.75 million during this period. The competitiveness effect from 2014 to 2019 was $173.18 \%$. After the "Belt and Road" initiative was put forward, the contribution rate of comprehensive competitiveness effect reached $158.55 \%$, which greatly promoted the growth of China's agricultural exports to Kazakhstan. In 2019, the proportion of total agricultural exports to Kazakhstan in 
total agricultural imports increased by $2.05 \%$ compared with that in 2014. In the two stages from 2002 to 2013, the contribution of comprehensive competitiveness effect is small, and it has little impact on export. The volatility of commodity competitiveness effect, another component of competitiveness effect, increases. From 1998 to 2001, the contribution rate of inhibiting effect of commodity competitiveness was $-3.45 \%$ indicating that China's agricultural exports could not concentrate on agricultural products whose export share increased rapidly. From 2002 to 2008, the contribution rate of commodity competitiveness effect was $-0.97 \%$. However, from 2009 to 2013, due to the impact of the global financial crisis, the agricultural trade between the two countries was affected by the overall economic environment, and the contribution of commodity competitiveness effect decreased, accounting for $-6.84 \%$. After the implementation of "Belt and Road" strategy, the customs clearance procedures between the two countries are simple, which makes the trade of agricultural products more convenient, and the commodity competitiveness effect turns from negative to positive, with the contribution and contribution rate of 8.45 million US dollars and $14.62 \%$.

Table 3. The results of China's Export of CMS to Kazakhstan from 1998 to 2019

\begin{tabular}{|c|c|c|c|c|}
\hline \multirow[b]{3}{*}{ Influencing factors } & & \multicolumn{2}{|r|}{ Unit: dollars } \\
\hline & \multicolumn{2}{|c|}{ 1998-2001 } & \multicolumn{2}{|c|}{$2002-2008$} \\
\hline & Exports & $\begin{array}{c}\text { Contribution } \\
\text { rate }\end{array}$ & Exports & $\begin{array}{c}\text { Contribution } \\
\text { rate }\end{array}$ \\
\hline changes in export value & -7037495 & $-100 \%$ & 94337112 & $100 \%$ \\
\hline structural change effect & 6671630 & $94.80 \%$ & 137543909 & $145.80 \%$ \\
\hline world growth effect & 4141856 & $58.85 \%$ & 131132341 & $139.00 \%$ \\
\hline commodity effect & 2529774 & $35.95 \%$ & 6411568 & $6.80 \%$ \\
\hline competitiveness effects & -9752644 & $-138.58 \%$ & -7634315 & $-8.09 \%$ \\
\hline $\begin{array}{l}\text { comprehensive } \\
\text { competitiveness effects }\end{array}$ & -9509717 & $-135.13 \%$ & -6716686 & $-7.12 \%$ \\
\hline \begin{tabular}{|l|} 
commodity \\
competitiveness effects
\end{tabular} & -242927 & $-3.45 \%$ & -917629 & $-0.97 \%$ \\
\hline interaction effect & -3956481 & $-56.22 \%$ & -35572482 & $-37.71 \%$ \\
\hline pure second-order effect & -4894000 & $-69.54 \%$ & -22435171 & $-23.78 \%$ \\
\hline $\begin{array}{l}\text { dynamic second-order } \\
\text { effect }\end{array}$ & 37520 & $13.32 \%$ & -13137311 & $-13.93 \%$ \\
\hline \multirow[b]{2}{*}{ Influencing factors } & \multicolumn{2}{|c|}{$2009-2013$} & \multicolumn{2}{|c|}{ 2014-2019 } \\
\hline & Exports & $\begin{array}{c}\text { Contribution } \\
\text { rate }\end{array}$ & Exports & \begin{tabular}{|c|}
$\begin{array}{c}\text { Contribution } \\
\text { rate }\end{array}$ \\
\end{tabular} \\
\hline changes in export value & 108566715 & $100 \%$ & 57772191 & $100 \%$ \\
\hline structural change effect & 121018930 & $111.47 \%$ & -29244658 & $-50.62 \%$ \\
\hline world growth effect & 106240813 & $97.86 \%$ & -24422891 & $-42.27 \%$ \\
\hline commodity effect & 14778117 & $13.61 \%$ & -4821767 & $-8.35 \%$ \\
\hline competitiveness effects & -6160529 & $-5.67 \%$ & $\begin{array}{c}10004804 \\
2\end{array}$ & $173.18 \%$ \\
\hline \begin{tabular}{|l|} 
comprehensive \\
competitiveness effects
\end{tabular} & 1267180 & $1.17 \%$ & 91599863 & $158.55 \%$ \\
\hline $\begin{array}{l}\text { commodity } \\
\text { competitiveness effects }\end{array}$ & -7427709 & $-6.84 \%$ & 8448179 & $14.62 \%$ \\
\hline interaction effect & -6291686 & $-5.80 \%$ & -13031193 & $-22.56 \%$ \\
\hline pure second-order effect & -1065941 & $-0.98 \%$ & -8362287 & $-14.47 \%$ \\
\hline $\begin{array}{l}\text { dynamic second-order } \\
\text { effect }\end{array}$ & -5225745 & $-4.81 \%$ & -4668906 & $-8.08 \%$ \\
\hline
\end{tabular}

(3) Before and after the "Belt and Road" initiative was proposed, the interaction effect was mainly inhibitory effect.
The interaction effect mainly inhibits the growth of China's export of agricultural products to Kazakhstan, and the variation trend mainly presents an inverted " $U$ " shape. Before the "Belt and Road" initiative was put forward, the inhibition of interaction effect was gradually weakened, but after the initiative was put forward, the inhibition was strengthened.

As shown in Table 3, from 1998-2001 to 2009-2013, the contribution rate of interaction effect decreased from $-56.22 \%$ to $-5.80 \%$, indicating that the inhibiting effect on export growth was weakening. However, from 2014 to 2019 , the interaction effect increased to $-22.56 \%$, resulting in a decrease of 13 million US dollars of agricultural exports from China to Kazakhstan. The contribution rate of pure second-order effect from 1998 to 2001 was $-69.54 \%$, indicating that the interaction between the change of China's agricultural product competitiveness in Kazakhstan market and the change of Kazakhstan's import demand resulted in the decrease of export volume, which suppressed the export growth.The pure second-order effect was consistent with the variation trend of the interaction effect, which decreased to $-0.98 \%$ from 2009 to 2013 and the inhibiting effect gradually weakened. However, from 2014 to 2019, the negative effect began to strengthen and the inhibiting effect reached $-14.47 \%$, indicating that the change of China's agricultural product competitiveness was not well matched with the change of Kazakhstan's import demand after the implementation of the strategy. Compared with the pure second-order effect, the dynamic second-order effect weakens its promoting effect on export growth, but strengthens its inhibiting effect. The dynamic second-order from 1998 to 2001 had a positive effect on the growth of China's agricultural exports to Kazakhstan, with a contribution rate of $13.32 \%$, indicating that the increase in exports was caused by the interaction between the change of China's share of agricultural products in the Kazakhstan's market and the change of the product demand structure in the Kazakhstan's market. Since 2002, the dynamic secondorder effect has restrained the export growth, and the contribution rate of the dynamic second-order effect has reached $-8.08 \%$ from 2014 to 2019 .

\subsubsection{Results analysis on classification view}

As shown in Table 4, further classification analysis of the agricultural products of category 0 is carried out.

(1) Before and after the "Belt and Road" initiative was proposed, the structural change effect and world growth effect were opposite.

As shown in Table 4, during 1998-2013, that is, before the "Belt and Road" strategy came into effect, the structural effect mainly promoted the export growth of category 0 agricultural products, and the promoting effect gradually strengthened. The contribution rate of structural effect in 2009-2013 reached $276.32 \%$, while the contribution rate in $1998-2001$ was only $19.83 \%$. During the two stages including 2002-2008 and 20092013, China's exports to kazakhstan category 0 agricultural are $\$ 92.42$ million and $\$ 106.22$ million 
respectively. According to the further decomposition of CMS model, the growth effect is a more significant factor affecting the export growth of category 0 agricultural products in the structural effect. However, the commodity effect from 1998 to 2001 was $-61.63 \%$. The Asian financial crisis led to the mismatch between the category 0 agricultural products exported by China and the products imported by Kazakhstan with rapid growth. In 2002-2008 the growth effect reached $144.98 \%$, and commodity effect reached $74.01 \%$. However, after the "Belt and Road" initiative was put forward, the structural effect, growth effect and commodity effect all changed from positive to negative, and the contribution rates were $-94.02 \%,-51.66 \%$ and $42.36 \%$, respectively.

(2) Competitiveness effect is gradually strengthened.

As shown in Table 4, the promotion effect of competitiveness on China's export of category 0 agricultural products to Kazakhstan is gradually enhanced. Especially, the comprehensive competitiveness has increased significantly since the "Belt and Road" initiative was put forward, and the competitiveness effect reached $262.58 \%$ from 2014 to 2019. Competitiveness effect reached $-80.83 \%$ in 1998 2001, showing a drop in China's agricultural competitiveness on the market in kazakhstan. Based on the figure that the comprehensive competitiveness rate reached $-139.89 \%$, decreasing proposition of China's export of category 0 agricultural products in kazakhstan's imports market by $3.81 \%$ from 1998 to 2001, we can find that the inhibition on the agricultural products export growth is too large. However, the commodity competitiveness effect has a certain promoting effect, and the contribution rate is $59.06 \%$. Although the value of the comprehensive competitiveness effect in 20022008 and 2009-2013 is small, the competitiveness reflected is constantly enhanced. After the "Belt and Road" initiative puts forward, comprehensive competitiveness effect changed from negative (6.34\%) to positive $(174.15 \%)$. The contribution rate of commodity competitiveness effect increases to $88.42 \%$ between 2014 and 2019.

(3) The interaction effect is still inhibiting after the "Belt and Road" initiative was proposed.

As shown in Table 4, during 1998-2019, the interaction effect had a inhibiting effect on China's export of category 0 agricultural products to Kazakhstan, but the inhibiting effect weakened after the implementation of the "Belt and Road" strategy. Before 2014-2019, the restraints of the interaction effect and dynamic second-order effect on the growth of category 0 agricultural product exports from China to Kazakhstan gradually strengthened. From 2009 to 2013, the interaction effect was -135 million US dollars, and the contribution rate reached $-127.10 \%$. The dynamic second-order effect was -84.5 million US dollars, and the contribution rate was $-79.56 \%$, indicating that the matching degree between Category 0 agricultural products exported from China and products with expanded import demand from Kazakhstan was poor, especially the matching degree between the product demand structure. After the "Belt and Road" initiative was put forward, the proportion of interaction effect and dynamic second-order effect was $-68.55 \%$ and $-34.64 \%$, respectively, indicating that the consistency between China's agricultural export and Kazakhstan's agricultural import market gradually increase. The inhibition effect of pure second-order effect showed an inverted "U" trend, but the amplitude was not large. In 1998-2013, the pure second-order effect on China's category 0 agricultural product exports to kazakhstan that negative effects of agricultural products gradually strengthened, in 2009-2013, inhibiting effect reached $-47.54 \%$, which explains Kazakhstan import demand at this stage does not match with the change of the size of the Chinese's category 0 agricultural products export quotas.

Table 4 . The results of China's Export about category 0 of CMS to Kazakhstan from 1998 to 2019

\begin{tabular}{|c|c|c|c|c|}
\hline \multirow{3}{*}{ Influencing factors } & \multicolumn{4}{|c|}{ Unit:million dollars } \\
\hline & \multicolumn{2}{|c|}{ 1998-2001 } & \multicolumn{2}{|c|}{$2002-2008$} \\
\hline & Exports & \begin{tabular}{|c|}
$\begin{array}{c}\text { Contribution } \\
\text { rate }\end{array}$ \\
\end{tabular} & Exports & $\begin{array}{c}\text { Contribution } \\
\text { rate }\end{array}$ \\
\hline $\begin{array}{l}\text { changes in export } \\
\text { value }\end{array}$ & -8.3723 & $-100 \%$ & 92.4214 & $100 \%$ \\
\hline $\begin{array}{l}\text { structural change } \\
\text { effect }\end{array}$ & 1.66 & $19.83 \%$ & 202.3962 & $218.99 \%$ \\
\hline world growth effect & 6.8199 & $81.46 \%$ & 133.9923 & $144.98 \%$ \\
\hline commodity effect & -5.1598 & $-61.63 \%$ & 68.4039 & $74.01 \%$ \\
\hline competitiveness effects & -6.7674 & $-80.83 \%$ & -15.0099 & $-16.24 \%$ \\
\hline \begin{tabular}{|l|}
$\begin{array}{l}\text { comprehensive } \\
\text { competitiveness effects }\end{array}$ \\
\end{tabular} & -11.7122 & $-139.89 \%$ & -7.2553 & $-7.85 \%$ \\
\hline \begin{tabular}{|l|} 
commodity \\
competitiveness effects
\end{tabular} & 4.9448 & $59.06 \%$ & -7.7546 & $-8.39 \%$ \\
\hline interaction effect & -3.2648 & $-39.00 \%$ & -94.9649 & $-102.75 \%$ \\
\hline $\begin{array}{l}\text { pure second-order } \\
\text { effect }\end{array}$ & -2.0107 & $-24.02 \%$ & -70.9924 & $-76.81 \%$ \\
\hline $\begin{array}{l}\text { dynamic second-order } \\
\text { effect }\end{array}$ & -1.2541 & $-14.98 \%$ & -23.9725 & $-25.94 \%$ \\
\hline \multirow[b]{2}{*}{ Influencing factors } & \multicolumn{2}{|c|}{ 1998-2001 } & \multicolumn{2}{|c|}{$2002-2008$} \\
\hline & Exports & \begin{tabular}{|c|}
$\begin{array}{c}\text { Contribution } \\
\text { rate }\end{array}$ \\
\end{tabular} & Exports & $\begin{array}{c}\text { Contribution } \\
\text { rate }\end{array}$ \\
\hline $\begin{array}{l}\text { changes in export } \\
\text { value }\end{array}$ & 106.2232 & $100 \%$ & 57.2522 & $100 \%$ \\
\hline $\begin{array}{l}\text { structural change } \\
\text { effect }\end{array}$ & 293.5197 & $276.32 \%$ & -53.829 & $-94.02 \%$ \\
\hline world growth effect & 119.4531 & $112.45 \%$ & -29.5749 & $-51.66 \%$ \\
\hline commodity effect & 174.0666 & $163.87 \%$ & -24.2541 & $-42.36 \%$ \\
\hline competitiveness effects & -52.2842 & $-49.22 \%$ & 150.33 & $262.58 \%$ \\
\hline \begin{tabular}{|l|} 
comprehensive \\
competitiveness effects
\end{tabular} & -6.73 & $-6.34 \%$ & 99.707 & $174.15 \%$ \\
\hline \begin{tabular}{|l|} 
commodity \\
competitiveness effects
\end{tabular} & -45.5542 & $-42.89 \%$ & 50.623 & $88.42 \%$ \\
\hline interaction effect & -135.0123 & $-127.10 \%$ & -39.2489 & $-68.55 \%$ \\
\hline $\begin{array}{l}\text { pure second-order } \\
\text { effect }\end{array}$ & -50.4959 & $-47.54 \%$ & -19.4193 & $-33.92 \%$ \\
\hline $\begin{array}{l}\text { dynamic second-order } \\
\text { effect }\end{array}$ & -84.5164 & $-79.56 \%$ & -19.8296 & $-34.64 \%$ \\
\hline
\end{tabular}

\section{Conclusions and Recommendations}

This article uses the UNcomtrade database data while using modified CMS model to do the overall and classification of empirical research for China's agricultural products export to Kazakhstan. The results show that before 2014, the structure effect is main factor boosting the growth of China's agricultural products export to Kazakhstan, and competitiveness effect and interaction effect mainly inhibit export growth; After 2014, the main factor promoting export growth is the 
competitiveness effect, while the structural effect and interaction are mainly the inhibiting effect.

Kazakhstan is the place where the "Belt and Road" project was initiated. The two countries will have closer cooperation in the future. In order to promote the sound development of China's agricultural exports to Kazakhstan, the following measures can be taken:

- Improve China's agricultural export structure, speed up the response to the market demand changes of Kazakhstan's agricultural products, make timely adjustments, and improve the restraining effect of structural effects.

- During the new epidemic, many local outbreaks in China were related to the quality and safety of different products. Therefore, the quality and safety level of export agricultural products should be improved, and the quality supervision of the production, storage and transportation of agricultural products and other national processes should be strengthened, so as to improve the reliability and competitiveness of Chinese agricultural products.

- Build a cross-border e-commerce platform for agricultural products, and stimulate the import demand of Kazakhstan's agricultural products through applying science and technology.

\section{Acknowledgment}

This work was supported by the construction project of "Public Management", a key discipline with characteristics in Guangdong Province in 2016. "Internet Finance" course general education Research (2019J014)

\section{References}

1. X.B. Liu, T. Chen, Analysis on the structure and comparative advantage of Chinese agricultural products export to Kazakhstan, IAE 03, 81(2009)

2. X.Q. Zhang, X.S. Gong, Analysis on the changing trend of trade structure, comparative advantage and complementarity of agricultural products between China and Kazakhstan, WA, 10, 128(2014)

3. J.J. Han, F. Wei, Analysis on Comparative Advantage, Complementarity and Growth Potential of Sino-Kazakh Agricultural Trade, WA, 12, 134(2017)

4. Y.J. Cheng, Y.M. Sun, A Study on the Trade of Agricultural Products between China and Kazakhstan -- Based on the Perspective of Ternary Marginal Analysis, FEX, 02, 70(2020)

5. X.Y. Meng, Estimation and Prospect of Trade Potential of Chinese Agricultural Exports to Kazakhstan: An Empirical Study Based on Extended Gravity Model, MPM, 10, 10(2014)

6. $\mathrm{Y}$. Hu, The Urgency of Improving the Competitiveness from the Current Situation of SinoKazakh Agricultural Trade -- Also on Improving the
International Competitiveness of Xinjiang Agricultural Products, CES, 01, 59( 2009)

7. X.S. Gong, X.Q. Zhang, R.H. Zhang, Study on the Fluctuation Factors of China's Agricultural Exports to Kazakhstan Based on CMS Model, GAS, 20, 201(2014)

8. Y.P. Lu, X.F. Xiao, Analysis of Influencing Factors of Trade Pattern Fluctuation of Cashmere And Its Products In China -- Empirical Study Based on CMS Model, AEM, 04, 53(2019) 